\title{
A UTILIZAÇÃO DO PAGAMENTO POR SERVIÇOS AMBIENTAIS (PSA) COMO ESTRATÉGIA DE INCREMENTO PARA A TRANSIÇÃO AGROECOLÓGICA
}

\author{
IASMIM CARDOSO GOSSENHEIMER, M.SC. | UNIVATES \\ LUCIANA TURATTI, PhD.|UNIVERSIDADE DE SEVILHA
}

\section{INTRODUÇÃO}

A mudança na estrutura socioeconômica das nações com o crescimento da população, e a postura do homem em relação ao meio em que está inserido, corroboram com o fato de que a interação homem/natureza passou de uma relação de troca saudável, para uma exploratória dos recursos naturais.

Políticas de desenvolvimento agrícola oriundas da Revolução Verde, constituídas a partir da década de 1960, orientaram a modernização de propriedades, e conforme Muller, Lovato e Mussoi (2003), aprofundaram as desigualdades, a exclusão social no campo, especialmente em se tratando de agricultores familiares, contribuindo ainda para o esquecimento de conhecimentos tradicionais e saberes locais.

Desta feita, a agricultura baseada na monocultura, aplicação de insumos e utilização de agrotóxicos, tornou-se uma das atividades mais nocivas ao meio ambiente. Apesar de tal constatação a transição da agricultura convencional para agroecológica encontra barreiras de ordem social, jurídico, ambiental e econômica, a despeito de haverem ferramentas para seu estímulo.

Um dos mecanismos que tem despontado como forma de incentivo às práticas sustentáveis é o Pagamento por Serviços Ambientais (PSA), que condiciona o recebimento de um benefício à prestação de um serviço ambiental.

Simões (2014) cita que a ideia de PSA surge a partir constatação de que é necessária a preservação dos serviços ambientais, para a continuidade da vida na terra. Deste modo, o objetivo deste trabalho foi verificar de que forma o instrumento econômico PSA pode contribuir para a transição da agricultura convencional para agroecológica.

No que tange à transição agroecológica, ações coletivas se mostram positivas como cooperativas e associações que, organizadas econômico e ambientalmente, buscam o mesmo propósito socioambiental.
É preciso que se tenha claro que, para a construção de uma agricultura sustentável é necessário que se façam presentes as dimensões ecológicas, econômicas, sociais, políticas, culturais e éticas da sustentabilidade. Isso implica em mudanças estruturais entre as quais Caporal (2009) cita a reforma agrária e o acesso aos meios de produção.

O PSA, entretanto, não deve ser assumido como uma ideia mercadológica, sendo visto apenas pelo viés econômico do incentivo recebido pela proteção ambiental prestada. Deve sim ser visto pela ótica da externalidade positiva, em consonância com o princípio do protetor-recebedor, onde o PSA proporcionado, se vincula a proteção ambiental.

Ou seja, a proteção ambiental deve ser algo intrínseco da atividade executada nas propriedades rurais em suas mais diversas atividades, sendo o PSA uma bonificação a esse serviço prestado.

Deste modo, o PSA deve ser um instrumento de estímulo econômico e de valorização de hábitos comuns aos produtores rurais familiares, que ao gerenciarem suas propriedades de forma ecologicamente correta através da agroecologia geram serviços ambientais.

\section{REFERÊNCIAS}

CAPORAL, F.R. Agroecologia: uma nova ciência para apoiar a transição a agriculturas mais sustentáveis. In.: CAPORAL, F.R. (Org.) Agroecologia: uma ciência do campo da complexidade. Brasília, 2009.

MULLER, J.M.; LOVATO, P.E.; MUSSOI, E.M. Do Tradicional ao Agroecológico: as veredas da transição (o caso dos agricultores familiares de Santa Rosa da Lima/SC). Eisforia (UFSC), Florianópolis, v.1, n.1, p.98121, 2003.

SIMÕES, M.S. Pagamento por Serviços Ambientais sob uma ótica econômico-ecológica e institucionalista: reconciliando teoria e prática. Dissertação (Mestrado em Economia) Universidade Federal de Uberlândia, 2014. 
